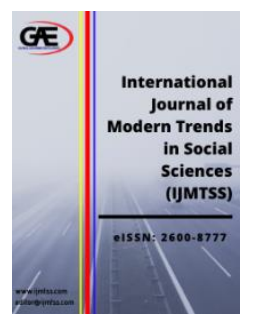

\author{
INTERNATIONAL JOURNAL OF \\ MODERN TRENDS IN \\ SOCIAL SCIENCES \\ (IJMTSS) \\ WWW.ijmtss.com
}

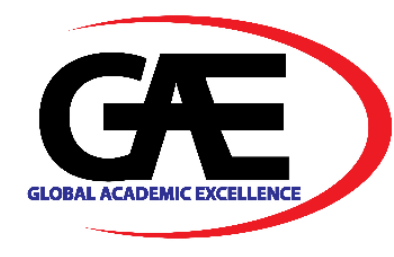

\title{
MEASURING THE GAP IN EMPLOYABILITY SKILLS AMONG MALAYSIAN GRADUATES
}

\author{
Janitha Nadarajah ${ }^{1}$ \\ 1 Centre for American Education, Sunway University, Malaysia \\ Email: janithan@sunway.edu.my
}

\section{Article Info:}

Article history:

Received date: 16.12 .2020

Revised date: 30.12 .2020

Accepted date: 09.02.2021

Published date: 03.03.2021

\section{To cite this document:}

Nadarajah, J. (2021). Measuring the Gap in Employability Skills among Malaysian Graduates. International Journal of Modern Trends in Social Sciences, 4 (15), 81-87.

DOI:10.35631/IJMTSS.415007

This work is licensed under CC BY 4.0

\section{(1)(1)}

\begin{abstract}
:
This research relates to the issue of unemployment among the local graduates and lack of employability skills. The objective of this research is to measure the employability skills among graduates from higher education institutions in Malaysia. The research identifies the gap in employability among the graduates and the competencies needed in the job market. 300 graduates from higher education institutions in Malaysia participated in this research. The findings of this research revealed that the graduates are equipped with most of the generic employability skills such as ICT skills, teamwork, leadership skills, and good time management. However, the graduates would still need to improve their communication, problem-solving and analytical skills. The research also found a mismatch in the employability skills between the graduates and job market requirements.
\end{abstract}

Keywords:

Employability Skills, Job Market Skills

\section{Introduction}

Malaysia has been having a prolonged problem concerning unemployment among the graduates in the country. It has already been almost 12 years and this problem remains in the country. The Higher Education Minister reported that almost 55,000 graduates remained unemployed in 2016, six months after the completion of their studies (Ministry of Education, 2016). In fact, the percentage of graduates unemployed from 2011 until 2015 has remained the same. The Graduate Trace study by the Ministry of Education that the graduates were finding it difficult to obtain jobs after 6 months of their completion of the degree (Ministry of Education, 2015). The Ministry of Education Graduate Tracer study in 2018 shows almost 60 


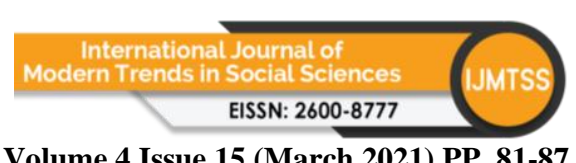

Volume 4 Issue 15 (March 2021) PP. 81-87

DOI 10.35631/IJMTSS.415007

percent of the graduates remain unemployed even after one year of graduation (Ministry of Education, 2018).

There are many reasons why the graduates unemployed remains high, but the most common reason gives my most employers and industry players is that the graduates lacks certain employability skills. The Malaysian Employers Federation (MEF) salary survey showed that in recent years shows there has been no improvements in the quality of Malaysian graduates in term of English language proficiency and communication skills (Walters, 2016). The MEF salary surveys between 2010 and 2016 among employers found that graduates lacks employability skills and language proficiency (Malaysian Employers Federation, 2016). Other common problems among Malaysia graduates are a low interpersonal relationship, passive, lack of initiative, not independent, attitudes problem, poor teamwork, not willing to learn, selfish and demand for high salary (Sieng and Yussof, 2017).

Unemployed graduates are found to be lacking in various employability skills and knowledge such as communication, soft skills, problem-solving skills, and technical skills (Omar and Rajoo, 2016). Malaysian employers have continuously provided feedback that the graduates lack English language proficiency, communication skills, analytical skills, and critical thinking (Cheong, Fernandez-Chung and Leong, 2016). The general feedback from employers indicates that there is a gap between what the job market requires and the graduate's competencies after completing their degree.

The objective of this research was to measure Malaysian graduate's employability skills based on the $21^{\text {st }}$ century generic employability skills categories. The second objective was to identify the gap between graduate's competencies and job market requirements in selected categories of employability skills. The categories of the employability skills used in this research is defined in the literature review.

\section{Literature Review}

Employability skills are transferable skills that represent essential functional and enabling knowledge, skills and attitudes required by the 21st century workplace (SCANS, 1991). Humberg and Velden (2017) highlighted on some of the employability skills graduates are expected to have in the $21^{\text {st }}$ century, they include ICT skills, problem solving and analytical skills, ability to learn, communication skills and interpersonal skills. The generic employability skills are required in the $21^{\text {st }}$ century is widely applicable across most job and is grouped into three broad categories (OECD, 2001; Humberg \& Velden, 2017):

i) Inter-personal skills include teamwork and leadership capabilities which helps the interaction among human resources and increase performance in the workplace.

ii) Intra-personal skills include motivation, ability to learn and adopt to changes, time management, problem solving skills, effective communication, and analytical skills. These skills are important for the graduates to be flexible and improve their professional expertise in the workplace.

iii) Technological or Information, Communication and Technology (ICT) skills which looks at the graduate's capability of using and operating ICT tools and systems. These skills are important to determine whether the graduates can use technology and innovation in their work. 


\section{Methodology}

The measurement of the graduate's employability skills in this research will focus on the category of generic skills identified by OECD (2001) and Humberg \& Velden (2017). The generic skill that are essential for graduates were grouped into three broad categories that are interpersonal skills, intrapersonal skill and ICT skills. In addition, this research will also measure specific skills that were identified under each category such as leadership skills, communication skills, problem solving skills, analytical skills, time management and teamwork.

The data collection for this research was divided into two sections. First was primary data collection from the graduates on their employability skills and competencies identified above. The data collection was conducted using questionnaire among 300 graduates with minimum qualification of degree from public and private higher education institution in Malaysia.

The second data collection was to identify and summarize the skills and competencies that required by in the current job market. The data collection covered 100 graduate entry jobs advertised through newspapers and job websites to narrow down the skills and competences that are required in the job market. The skills were identified and matched to specific skills of the generic employability skills.

\section{Results and Discussion}

\section{Employability Skills of Graduates}

A summary of the overall employability skills of the graduates is shown in Figure 3.1. The mean scores of the graduate's employability skills were 3.82 out of 5. This shows the graduates are moderately competent in terms of employability skills. The average competencies of the graduates in the three broad categories of generic employability skills are almost the same, but graduates seem to be most competent in ICT skills with a mean score of 3.87 out 5 . Followed by interpersonal skills with a mean score of 3.84 and the lowest mean score for Intrapersonal skills with 3.75. The employability skills score for graduate's ranges from a score of $1-5$ and the graduate's skills were categorized with descriptors such as poor, moderate and good. The descriptive analysis shows that graduates have a moderate level of employability skills.

Figure 1.1 Graduates Employability Skills

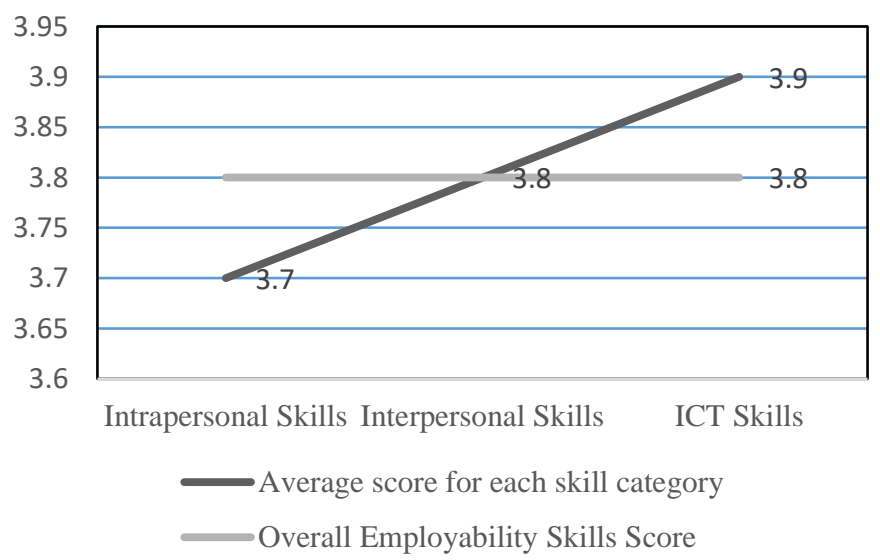

Note: $\mathrm{N}=300$, employability skills the Score ranges from Poor (1- 2), Moderate (2.1- 3.9), Good (4-5) 


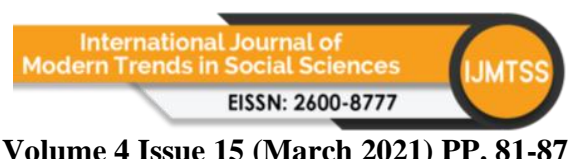

Volume 4 Issue 15 (March 2021) PP. 81-87

DOI 10.35631/IJMTSS.415007

In some of the specific employability skills identified in this research, the graduates have average competencies in Leadership skills and teamwork. The graduates are competent in their ability to meet deadlines but are not very confident with the ability to motivate others to work. Graduate also average competencies to give direction and delegate work. The graduates perceive themselves to be good in their listening skills and teamwork. However, the graduates are still unable to place team goals ahead of their own goals.

The graduates seem to be moderately competent in terms of intrapersonal skills. The results of this analysis show that graduates are still not fully confident with their communication skills. Graduates are specifically not confident in doing presentations in English and communicating in English, especially in the working environment. However, the graduate felt they have good time management and can complete a task within a given timeframe. Graduates were found to be moderately competent in terms of problem-solving and analytical skills, but the graduates were not confident in resolving conflicts with others and still lack the capacity for analysis and synthesis. The graduates feel that they can understand problems and gather facts, however they are still not confident in analysing and finding solutions on their own.

Table 1.1 Graduates skills and competencies

\begin{tabular}{lc}
\hline Skills/Competencies & Mean Scores \\
\hline Teamwork & 3.86 \\
Leadership & 3.82 \\
Communication & 3.72 \\
Problem-solving & 3.70 \\
Time Management & 3.85 \\
Basic ICT Skills & 4.05 \\
Advance ICT skills & 3.49 \\
\hline
\end{tabular}

Note: $\mathrm{N}=300$, employability skills the Score ranges from Poor (1- 2), Moderate (2.1-3.9), Good (4-5)

The graduates were most competent in ICT skills. The graduates perceive themselves to be very confident with basic ICT tools such as usage of email, mobile phone services, power point, prepare reports/assignments and using internet for data collection. The graduates seem to have a moderate ability in using the spreadsheet and using the computer to handle presentations. As for advance user of ICT tools the graduates seem to lack in term of participating in forums/chats and operating software's.

\section{Skills Required in The Job Market}

The employability skills required in the job market were mostly on the specific skills that were identified in the generic employability skills. The most common skill in demand in the job market was communication skills. 70 percent of the jobs required good communication skills for most of the jobs. Almost 31 percent of the employers required analytical skills as an important requirement in their offered jobs. Organizing, planning, writing skills, and report writing were also important skills required in some jobs (27.9 percent). 26.5 percent of the jobs required good numeracy skills. Some jobs require good time management and the ability to meet deadlines ( 26.5 percent). Being accurate and attentive ( 25 percent) was also required by some employers. 23.5 percent of the jobs required good teamwork. Almost 20 percent of the 
jobs required motivation and leadership skills. 17.6 percent of the jobs required computer skills and flexibility.

Table 1.2 Job market skills

\begin{tabular}{lc}
\hline Employability Skills & Percentage \\
\hline Communication Skills & 70.1 \\
Analytical Skills & 31 \\
Time Management & 26.5 \\
Teamwork & 23.5 \\
Motivation & 23.5 \\
Leadership skills & 22.06 \\
Interpersonal skills & 19.1 \\
Basic ICT skills & 17.6 \\
\hline
\end{tabular}

Note: Percentage is based on the number of jobs that required the skill $(\mathrm{N}=100)$.

\section{Conclusion}

The findings of this research showed that graduates are competent in all three broad categories of generic employability skills. The graduate's highest competency was ICT skills followed by Intrapersonal skills and lastly Interpersonal skills. In terms of more specific employability skills, some graduates indicated that they are still not fully competent in their communication, presentation, and problem-solving skills. These specific skills fall under the broad category if intrapersonal skills. However, the most highly demanded skill required in the job market was good communication and analytical skills.

There is an obvious mismatch between expectations in the job market and local graduate's in term of specific employability skills in Malaysia. The graduates are most competent in Basic ICT skills, leadership skills, teamwork, and time management. However, the job market skills requirements are communication skills and analytical skills. Malaysian graduates are unemployed not because they lack employability skills, but mainly it's because of the gap.

The graduates perceived themselves to be equipped with the broad categories of the generic employability skills, however the mismatch still exist in some of the specific employability skills under each category. This leads to the major problem of graduate.

\section{Figure 1.2 Mismatch of Skills Expectations}
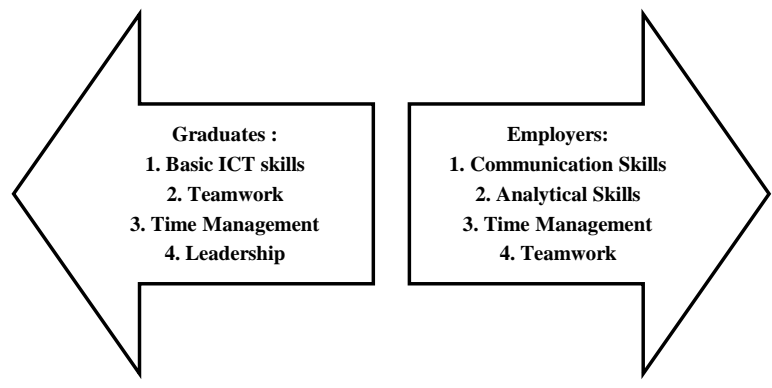


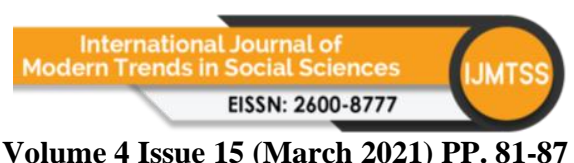

Volume 4 Issue 15 (March 2021) PP. 81-87

DOI 10.35631/IJMTSS.415007

The impact of the mismatch of skills among graduates and employers has led to an increasing number of Malaysian graduates unable to obtain jobs even after 6 months of graduation. The lack of job market skills and prolonged unemployment among Malaysia graduates has also brought negative impact on the graduates. The major impact is on the average graduate's salary which has remained stagnant in the last five years (Bank Negara Malaysia, 2017). The graduate's unemployment among youths in Malaysia are three times higher than the national unemployment rate. The graduates tend to prioritize and adapt to skills that are easy for them. The lack of incentives to learn and adapt new skills and competencies will only make the employability gap wider.

\section{References}

Ahmad, N. A., Kenayathulla, H. B., and Idris, A. R. (2017). Employability skills for hospitality Students in Malaysia. MOJEM: Malaysian Online Journal of Educational Management, 5(4), 63-86.

Ali, Z., Hassan, H. H., Radzuan, N. R., Sabaruddin, A., Dato'Yaakub, M. H., Baharum, N., ... and Sakari, S. M. (2017). A Case Study of Entrepreneurial Skills of Higher Education Graduates in an Islamic College in Malaysia. International Journal of Humanities Technology and Civilization, 1(2).

Bank Negara Malaysia (2017), Bank Negara Annual report 2016. Kuala Lumpur: Bank Negara Malaysia, 99-106.

Cheong, K. C., Hill, C., Fernandez-Chung, R., and Leong, Y. C. (2016). Employing the 'unemployable': employer perceptions of Malaysian graduates. Studies in Higher Education, 41(12), 2253-2270.

Humburg, M., and Van der Velden, R. (2017). What is Expected of Higher Education Graduates in the Twenty-First Century? The Oxford Handbook of Skills and Training, 201.

Malaysian Employers Federation. (2016). MEF Salary Survey for Executives 2016. Kuala Lumpur, Malaysia: Malaysian Employers Federation.

Ministry of Education Malaysia (2015). Malaysia Education Blueprint 2015-2025 (Higher Education). Putrajaya: Ministry of Education Malaysia.

Ministry of Higher Education Malaysia (2012). The National Graduate Employability Blueprint 2012-2017. Putrajaya: Ministry of Higher Education Malaysia.

Ministry of Higher Education Malaysia (2017). Graduate Tracer Study Trends 2006 - 2016. Retrieved from http://graduan.mohe.gov.my/skpg-report.

Ministry of Higher Education Malaysia (2019). Graduate Tracer Study 2018. Putrajaya: Ministry of Higher Education Malaysia.

Ministry of Higher Education Malaysia (2018). Graduate Tracer Study 2017. Putrajaya: Ministry of Higher Education Malaysia.

Ministry of Higher Education Malaysia (2017). Graduate Tracer Study 2016. Putrajaya: Ministry of Higher Education Malaysia.

Ministry of Higher Education Malaysia (2016). Graduate Tracer Study 2015. Putrajaya: Ministry of Higher Education Malaysia.

Ministry of Higher Education Malaysia (2015). Graduate Tracer Study 2014. Putrajaya: Ministry of Higher Education Malaysia.

Omar, C. M. Z. C., and Rajoo, S. (2016). Unemployment among graduates in Malaysia. International Journal of Economics, Commerce and Management, 4(8), 367-374.

Organisation for Economic Co-operation and Development (OECD). (2001). Competencies for the knowledge economy. Education Policy Analysis , Chapter 4, 100-118. 
Robert Walters. (2016). Robert Walters Global Salary Survey 2016. 303-316. Retrieved from https://www.robertwalters.com.my/content/dam/salary-survey-2016.pdf.

Sieng, L. W., and Yussof, I. (2017). Comparative study of Malaysia human capital with selected ASEAN and Developed Countries: A fuzzy TOPSIS method. GeografiaMalaysian Journal of Society and Space, 11(6).11-22.

Suleman, F. (2017). The employability skills of higher education graduates: insights into conceptual frameworks and methodological options. Higher Education, 1-16.

Yusof, N., and Jamaluddin, Z. (2017). Graduate employability and preparedness: A case study of University of Malaysia Perlis (UNIMAP), Malaysia. Geografia-Malaysian Journal of Society and Space, 11(11), 129-143.

Yunus, A., Rashid, F. H., and Ismail, L. (2017, January 15). Enhancing employability: Programmes, initiatives to help unemployed, fresh graduates. New Straits Times. Retrieved from https://www.nst.com.my/news/2017/01/204393/enhancingemployability-programmes-initiatives-help-unemployed-fresh-graduates.

Yoke, T. C., and Ngang, T. K. (2017). A study on soft skill development among final year diploma in business studies students. MOJEM: Malaysian Online Journal of Educational Management, 3(2), 32-50.

Yoong, D., Don, Z. M., and Foroutan, M. (2017). Prescribing roles in the employability of Malaysian graduates. Journal of Education and Work, 30(4), 432-444. 